\title{
Bone mineral densities in individuals with Gilbert's syndrome: A cross-sectional, case-control pilot study
}

\author{
GY Minuk MD¹, R Greenberg BSc ${ }^{1}$, J Uhanova MD MSc ${ }^{1}$, K Hawkins RN ${ }^{1}$, WD Leslie MD²
}

GY Minuk, R Greenburg, J Uhanova, K Hawkins, WD Leslie. Bone mineral densities in individuals with Gilbert's syndrome: A cross-sectional, case-control pilot study. Can J Gastroenterol 2009;23(6):431-436.

BACKGROUND: Unconjugated bilirubin inhibits osteoblastic proliferative activity in vitro, raising the possibility that Gilbert's syndrome (GS) patients are at increased risk of osteoporosis.

OBJECTIVES: To compare bone mineral density (BMD), serum parathyroid hormone (PTH), C-telopeptide (CTX) and osteocalcin levels in GS subjects versus matched controls in a cross-sectional, case-control study.

METHODS: BMD determinations were obtained with central dualenergy $\mathrm{x}$-ray absorptiometry. Serum PTH, CTX and osteocalcin levels were measured by enzyme immunoassay.

RESULTS: A total of 17 GS and 30 control subjects were studied. Overall, there were no significant differences in BMD, PTH, CTX or osteocalcin levels between the two groups. However, when older (older than 40 years of age) and younger ( 40 years of age and younger) cohorts were considered separately, the older GS cohort had significantly decreased total hip BMD, T scores and Z scores, and femoral neck BMD, $T$ scores and $\mathrm{Z}$ scores $(\mathrm{P}<0.005$ for each parameter, respectively) compared with older control subjects. Serum osteocalcin levels were lower in the older versus younger GS cohort $(P=0.006)$. An inverse correlation existed between all subjects' serum unconjugated bilirubin levels and total body BMD determinations $(r=-0.42 ; \mathrm{P}=0.04)$. On univariate analysis, the association between serum unconjugated bilirubin and total body BMD was not significant $(\mathrm{P}=0.066)$, nor was serum unconjugated bilirubin identified as a risk factor for low BMD when entered into multivariate analyses.

CONCLUSIONS: The results of the present pilot study warrant further research involving larger numbers of subjects and longitudinal measurements to determine whether GS is associated with decreased BMD, particularly in older GS subjects.

Key Words: Bone fractures; Cholestasis; Chronic liver disease; Gilbert's syndrome; Hyperbilirubinemia; Osteoblasts; Osteopenia; Osteoporosis; Unconjugated bilirubin

ilbert's syndrome (GS) is a common condition (occur$\mathbf{J}_{\text {ring in } 3 \% \text { to } 7 \% \text { of the adult population) characterized }}$ by chronic unconjugated hyperbilirubinemia in the absence of other biochemical or histological evidence of liver disease (1). The hyperbilirubinemia in GS patients is usually mild (plasma total bilirubin concentration $29 \mu \mathrm{mol} / \mathrm{L}$ to $100 \mu \mathrm{mol} / \mathrm{L}$ ) and associated with impaired hepatic clearance due to a deficiency of the enzyme bilirubin uridine diphosphate (UDP)glucuronosyltransferase in the liver (2). Often, the diagnosis

\author{
Densité minérale osseuse chez des individus \\ atteints du syndrome de Gilbert : Étude pilote \\ transversale avec cas-témoins
}

CONTEXTE : La bilirubine non conjuguée inhibe l'activité proliférative des ostéoblastes in vitro, suggérant la possibilité que le syndrome de Gilbert (SG) expose les patients qui en sont atteints à un risque accru d'ostéoporose.

OBJECTIF : Comparer la densité minérale osseuse (DMO) et les taux sériques d'hormone parathyroïdienne (PTH), de télopeptide C (CTX) et d'ostéocalcine chez des sujets atteints de SG, comparativement à des témoins assortis, dans le cadre d'une étude transversale avec cas-témoins. MÉTHODE : Les DMO ont été obtenues au moyen de tests d'absorptiométrie biphotonique centrale et les taux sériques de PTH, de CTX et d'ostéocalcine, au moyen d'immunodosages enzymatiques.

RÉSULTATS : L'étude a regroupé en tout 17 sujets atteints de SG et 30 témoins. Dans l'ensemble, on n'a noté aucune différence entre les DMO ou les taux de PTH, de CTX ou d'ostéocalcine des deux groupes. Toutefois, lorsqu'on a analysé séparément les cohortes plus âgées (de plus de 40 ans) et plus jeunes (de 40 ans et moins), les sujets plus âgés atteints de SG présentaient une baisse significative de la DMO totale au niveau de la hanche, scores T et Z, et de la DMO du col du fémur, scores T et $\mathrm{Z}$ ( $\mathrm{p}<0,05$ pour chaque paramètre respectivement), comparativement aux sujets témoins plus âgés. Les taux sériques d'ostéocalcine étaient moindres chez les sujets atteints de SG plus âgés, comparativement aux plus jeunes $(p=0,006)$. Une corrélation inverse a été observée entre les taux sériques de bilirubine non conjugué et la DMO pour le corps entier $(\mathrm{r}=-0,42 ; \mathrm{p}=0,04)$. À l'analyse univariée, le lien entre la bilirubine non conjuguée sérique et la DMO du corps entier n'a pas été significatif $(\mathrm{p}=0,066)$, et la bilirubine sérique non conjuguée n'a pas non plus été considérée comme un facteur de risque de DMO faible lors de son inclusion dans des analyses multivariées.

CONCLUSION : Les résultats de la présente étude pilote justifient que l'on approfondisse la recherche auprès de cohortes plus nombreuses au moyen de mesures longitudinales afin de déterminer si le SG est associé à une baisse de la $\mathrm{DMO}$, particulièrement chez les sujets plus âgés atteints de la maladie.

Department of Medicine, ${ }^{1}$ Section of Hepatology; ${ }^{2}$ Section of Nuclear Medicine, University of Manitoba, Winnipeg, Manitoba

Correspondence: Dr GY Minuk, Section of Hepatology, John Buhler Research Centre, 715 McDermot Avenue, Winnipeg, Manitoba R3E 3P4.

Telephone 204-789-3204, fax 204-789-3987, e-mail gminuk@cc.umanitoba.ca

Received for publication September 1, 2008. Accepted December 20, 2008 
is chronic liver disease (CLD), particularly when cholestasis and associated hyperbilirubinemia are present (5-10). Indeed, metabolic bone disease (hepatic osteodystrophy) is a common finding in CLD patients and vertebral fractures have been reported in $3 \%$ to $44 \%$ of CLD patients (11-13).

The strong association between osteoporosis and CLD in general, and cholestasis in particular, raises the possibility that retained substances normally cleared by the hepatobiliary system may impair osteoblast and/or enhance osteoclast activity. Bile acids and bilirubin are the two major products retained during cholestasis. However, when added to normal human plasma in concentrations similar to those found in cholestasis, conjugated bile acids had no effect on the plasma mitogenic activity (PMA) of human osteoblast-like cells (14). Conversely, unconjugated bilirubin significantly decreased PMA in a dosedependent fashion without affecting cell viability (14). In addition, when unconjugated bilirubin was selectively removed from plasma by photobleaching, PMA returned to normal values (14).

The principal aim of the present pilot study was to determine whether the unconjugated hyperbilirubinemia associated with GS is associated with decreased total body bone mineral density (BMD).

\section{METHODS}

\section{Study populations}

Cases of GS were identified from the Section of Hepatology at the University of Manitoba's (Winnipeg, Manitoba) computerized outpatient database as individuals referred for assessment of isolated hyperbilirubinemia. The diagnosis was established if greater than $90 \%$ of the hyperbilirubinemia was due to an increase in the unconjugated fraction as measured by the total (diazo method) minus conjugated (Jendrassik-graf method) bilirubin, and other liver biochemistry testing (serum aminotransferases, alkaline phosphatase, gamma-glutamyl transferase, albumin and international normalized ratio for prothrombin times) and tests for hemolysis (reticulocyte count and serum haptoglobin levels) were normal. In the majority of cases, two or three measurements of serum unconjugated bilirubin levels were made during the course of the one year before enrolment. For the present study, the mean value of the various determinations was used. In other cases, the levels obtained just before bone density determinations were used. All laboratory testing was performed by the Clinical Chemistry and Hematology Departments at the Health Sciences Centre, Winnipeg, Manitoba.

\section{Controls}

Control subjects consisted of hospital staff or visitors responding to study advertisements posted in the hospital and adjacent public venues. They were matched with subjects (one to two matched controls for each subject) based on age ( \pm 5 years), sex, height $( \pm 1 \mathrm{~cm})$, weight $( \pm 5 \mathrm{~kg})$ and menopausal status using a computer algorithm that minimized the normalized sum of square differences. None of the controls (or GS subjects) provided a history of liver disease or alcohol abuse; had abnormal liver biochemistry or evidence of hemolysis; were undergoing antiresorptive therapies; taking medications affecting bone or mineral metabolism; were on hormone replacement therapy; were pregnant; had recently been pregnant or were breastfeeding (within six months) due to transient, reversible changes in BMD associated with these states. In addition, subjects were not previously treated with glucocorticoids, thyroid hormone replacements and antiseizure medications, and did not have other recognized risk factors for bone loss. No attempt was made to match subjects based on smoking history.

\section{Bone density determinations}

All subjects underwent bone density measurements of the lumbar spine, total hip, femoral neck and total body with central dual-energy x-ray absorptiometry (DXA) (QDR-4500; Hologic, USA). The instrument was cross-calibrated with other instruments used in the Canadian Multicentre Osteoporosis Study (CaMos). Quality assurance was performed in accordance with CaMos procedures (15). Daily quality control with an anthropomorphic phantom yielded long-term precision of less than $0.5 \%$, and the in vivo coefficient of variation was $1.0 \%$ to $1.7 \%$ at the measurement sites. All results were carefully reviewed by a single study investigator (WDL) who had experience in clinical and research DXA. Scans were acquired and analyzed using the manufacturer's specifications and White reference data to provide areal measures of bone density including BMD $\left(\mathrm{g} / \mathrm{cm}^{2}\right), T$ score (number of SDs that BMD is above or below average peak BMD for young normal adults) and Z score (number of SDs that BMD is above or below average BMD for agematched normal adults).

\section{Bone serum markers}

Serum C-telopeptide (CTX), parathyroid hormone (PTH) and osteocalcin levels were determined by testing morning fasting blood samples with enzyme immunoassays on a Roche Modular Analyzer (Roche Diagnostics, Canada) using commercially available kits (beta-CrossLaps, parathyroid hormone and N-MID Osteocalcin [Roche Diagnostics, Canada], respectively).

\section{Statistics}

Categorical variables were evaluated using $\chi^{2}$ analysis. The $\chi^{2}$ test of association was used to examine differences in demographic factors. Continuous variables were assessed using the Student's $t$ test or ANOVA (Mann-Whitney U test or KruskalWallis tests as appropriate). An ANOVA was performed to test for possible age-sex interaction. To examine whether unconjugated bilirubin levels correlated with total body BMD, the Spearman rank correlation test was used. Multivariate regression analysis was used to assess whether and how patients' demographic and clinical characteristics were associated with total BMD (the principal outcome variable). A backward stepwise procedure with multiple regression modelling was used to determine the final set of independent factors predictive of BMD in GS individuals. The overall model performance was evaluated by the ANOVA test of the models, and variables significant at the $\mathrm{P}<0.05$ level remained in the model.

Statistical significance was considered present when a $P$ value fell below 5\% in all analyses. The 95\% CI for means and for significant differences were calculated. Statistical analysis was performed using NCSS statistical software (NCSS \& PASS, USA).

\section{Ethics}

The present study was approved by the University of Manitoba Conjoint Ethics Committee for Human Experimentation. All subjects provided written informed consent before entry into the study. 


\section{RESULTS}

Demographics

A total of 17 GS and 30 control subjects met the study inclusion criteria and provided informed consent to participate (Figure 1). Seven of the GS (41\%) and 14 control (47\%) subjects were men (male to female ratio of 0.7 and 0.5 , respectively). Of the female subjects, one of 10 GS (10\%) and two of 16 control $(12.5 \%)$ subjects were postmenopausal. The mean ( \pm SD) ages of the study groups were $41 \pm 12$ and $40 \pm 11$ years, respectively. Median ages were 40.1 and 38.8 years, respectively (ranges 22 to 63 and 22 to 64 years, respectively). Thus, eight GS and 12 control subjects were 41 years of age or older. Of these, $50 \%$ and $58 \%$ were men, respectively. The mean body mass index of GS subjects was $23.2 \pm 3.8 \mathrm{~kg} / \mathrm{m}^{2}$ versus $23.5 \pm 3.0 \mathrm{~kg} / \mathrm{m}^{2}$ for controls.

\section{BMDs}

The results of the BMD determinations are provided in Figure 2. Overall, BMD levels were similar in GS and control subjects. However, in all skeletal regions studied (ie, spine, total hip, femoral neck and total body), BMD values in GS subjects were lower than in controls. When the cohorts of older GS and control subjects were analyzed separately, significant differences were observed. Specifically, total hip and femoral neck BMD, T scores and Z scores were significantly lower in older GS subjects than in older controls $(\mathrm{P}<0.005)$. In the younger age cohorts, only the femoral neck BMD T scores were significantly different in that younger controls had lower mean BMD determinations and $\mathrm{T}$ scores in this region $(\mathrm{P}<0.05)$.

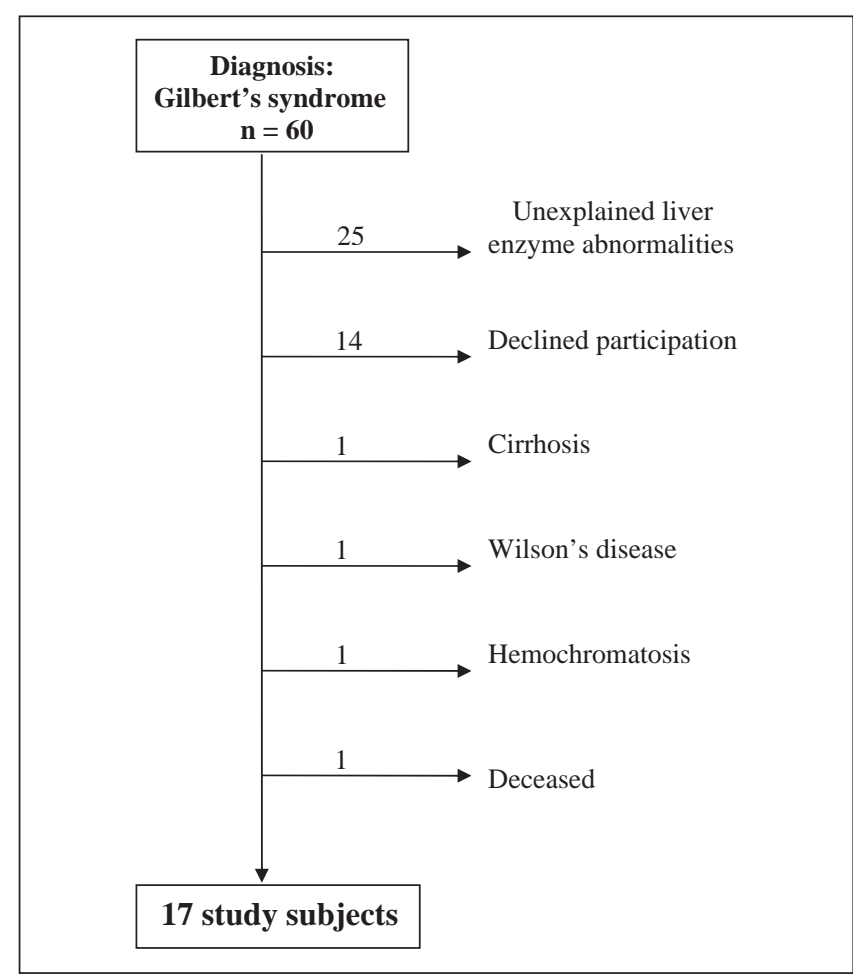

Figure 1) Gilbert's syndrome patient selection

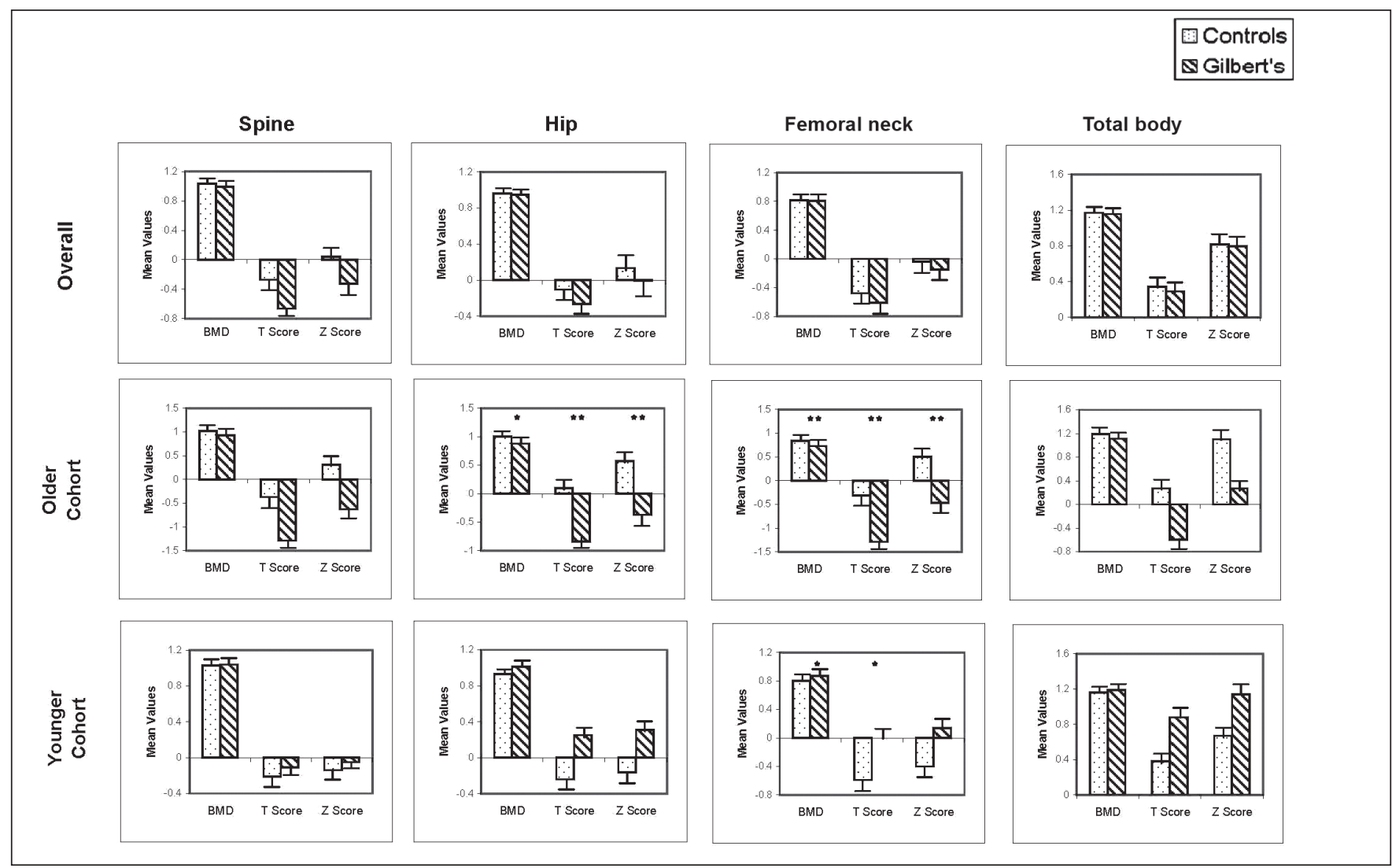

Figure 2) The results of bone mineral density (BMD) determinations (means \pm SD) of the spine, total hip, femoral neck and total body in 17 Gilbert's syndrome and 30 matched healthy control subjects when analyzed as an overall group (upper panel), older (>40 years [middle panel]) or younger ( $\leq 40$ years [lower panel]) cohort. P values represent differences between Gilbert's syndrome and control subjects.

$* P<0.05 ; * * P<0.005$ 
TABLE 1

Serum parathyroid hormone (PTH), C-telopeptide (CTX) and osteocalcin levels in Gilbert's syndrome (GS) and control subjects

\begin{tabular}{|c|c|c|c|c|c|}
\hline & \multirow[b]{2}{*}{ Normal values (range) } & \multicolumn{2}{|c|}{ GS cohort, age } & \multicolumn{2}{|c|}{ Control cohort, age } \\
\hline & & $\leq 40$ years & $>40$ years & $\leq 40$ years & $>40$ years \\
\hline Subjects, $\mathrm{n}$ & - & 9 & 8 & 18 & 12 \\
\hline Mean/median age, years & - & $31.8 / 31.4$ & $52.2 / 51.8$ & $34.2 / 34.7$ & $52.5 / 51.9$ \\
\hline Male sex, $\mathrm{n}$ & - & 3 & 4 & 5 & 5 \\
\hline $\begin{array}{l}\text { Mean/median unconjugated } \\
\text { bilirubin, } \mu \mathrm{mol} / \mathrm{L}\end{array}$ & $(<13)$ & $28.6 / 26.8$ & $27.9 / 29.2$ & $6.5 / 6.5$ & $8.4 / 8$ \\
\hline PTH, ng/L (mean \pm SD) & $7-50$ & $25.4 \pm 3.8$ & $32.6 \pm 3.5$ & $35.5 \pm 5.6$ & $36.9 \pm 5.7$ \\
\hline $\mathrm{CTX}, \mathrm{pg} / \mathrm{mL}$ (mean $\pm \mathrm{SD})$ & $<584$ & $219 \pm 24$ & $252 \pm 29$ & $273 \pm 54$ & $226 \pm 79$ \\
\hline Osteocalcin, ng/mL (mean \pm SD) & $11-48$ & $24.2 \pm 1.5$ & $17.8 \pm 1.2^{*}$ & $20.1 \pm 3.5$ & $18.3 \pm 2.8$ \\
\hline
\end{tabular}

${ }^{*} P=0.006$ (osteocalcin in subjects $\leq 40$ years of age versus subjects $>40$ years of age)

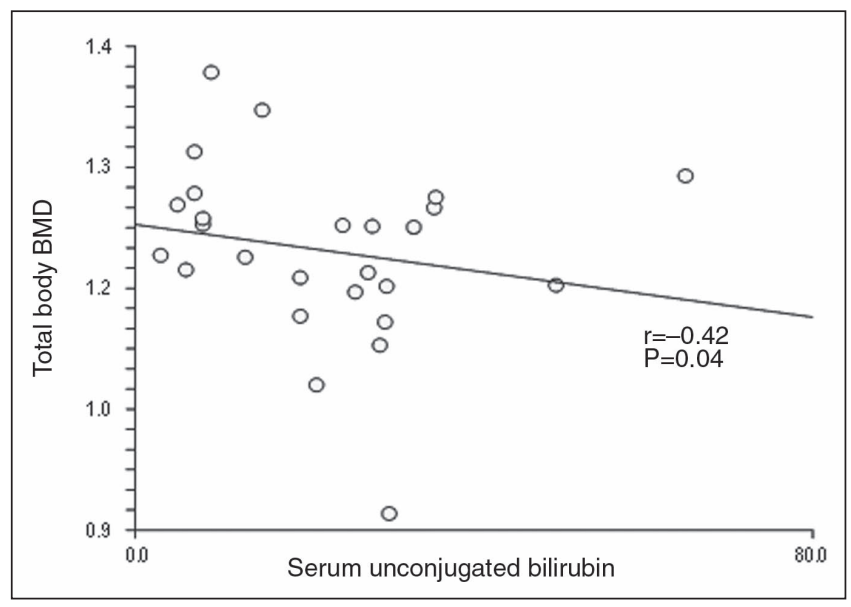

Figure 3) Total body bone mineral densities (BMD) as a function of mean serum unconjugated bilirubin levels in 17 Gilbert's syndrome subjects and nine control subjects in whom more than one unconjugated bilirubin level was available. There was a significant negative correlation between BMD determinations and unconjugated bilirubin levels $(r=-0.42 ; P=0.04)$

To achieve a sufficient number of subjects for statistical analysis, data from GS and control subjects were pooled to determine whether a correlation between total body BMD and serum unconjugated bilirubin levels existed. As shown in Figure 3, there was a significant negative correlation between these two variables $(r=-0.42 ; \mathrm{P}=0.04)$.

\section{Bone biomarkers}

Serum CTX, PTH and osteocalcin levels are presented in Table 1. There were no differences in the levels of these compounds when the overall or age-specific cohorts of GS and control subjects were compared. However, serum osteocalcin levels were significantly lower in the older GS cohort than in the younger GS cohort $(\mathrm{P}=0.006)$. This age-related difference was not demonstrated in the older and younger control cohorts $(\mathrm{P}=0.48)$.

\section{Univariate and multivariate analysis}

The results of univariate and multivariate analyses are presented in Table 2. Serum unconjugated bilirubin was not associated with total body BMD on univariate analysis $(\mathrm{P}=0.066)$. Candidate variables for multiple regression analysis included age (as a continuous variable), sex, body mass index, bone biomarkers (PTH, CTX and osteocalcin), GS and age-sex interaction. Of note, not all variables were included in the multivariate analysis
TABLE 2

Univariate and multivariate analyses for associations with total body bone mineral densities (BMD)

\begin{tabular}{lcc}
\hline & \multicolumn{2}{c}{ Total body BMD } \\
\cline { 2 - 3 } Variable & Univariate (P) & Multivariate (P) \\
\hline Age & 0.97 & 0.005 \\
Sex & 0.0002 & 0.006 \\
Body mass index & 0.39 & $\mathrm{NS}$ \\
C-telopeptide & 0.71 & 0.01 \\
Parathyroid hormone & 0.09 & 0.005 \\
Osteocalcin & 0.52 & $\mathrm{NS}$ \\
Menopause & 0.09 & - \\
Total bilirubin & 0.27 & - \\
Unconjugated bilirubin & 0.066 & - \\
Gilbert's syndrome & 0.61 & 0.86 \\
Age-sex interaction & - & $\mathrm{NS}$ \\
\hline
\end{tabular}

NS Not significant

because of inherent relationships between certain variables. For example, age and sex served as proxy for menopause status. Similarly, total and unconjugated bilirubin levels were inherently correlated with the grouping variable 'GS' ( $r=0.77$ and $\mathrm{r}=0.83$, respectively). As shown in Table 2, age, female sex, lower levels of CTX and higher levels of PTH were significantly associated with decreased total body BMDs.

\section{DISCUSSION}

The principal finding of the present pilot study was a significantly decreased total hip and femoral neck BMD in older GS subjects compared with age- and sex-matched controls. However, no such differences existed for the spine and total body BMD in these cohorts. While such site-specific differences may be a chance observation due to the small number of subjects studied, they are not unusual given the only modest correlation between BMD measurements from different skeletal sites (correlation coefficients typically range from 0.55 to $0.65)$ (16). In addition to being described in healthy individuals, site specificity is also a feature of disease states $(17,18)$. For example, lumbar spine trabecular bone is highly sensitive to corticosteroids, the hip to mechanical unloading in paraplegia, and the distal forearm to the action of PTH on peripheral cortical bone. Artifacts can also contribute to site-specific differences, particularly the lumbar spine, which is prone to degenerative sclerosis, vascular calcification and other ectopic calcium deposition. It is important to note, however, that of the bone density sites measured, the hip is believed to have the 
greatest clinical importance due to the results from this region not being confounded by osteoarthritis as much as other skeletal sites (particularly in older patients) and the strong correlation that exists between low bone densities in the hip and hip fractures (19).

Osteocalcin is a bone turnover marker synthesized by osteoblasts and deposited mainly in the extracellular matrix of bone $(20,21)$. In men, there is a slight decrease in serum osteocalcin up to the mid-50s in age, with relatively stable levels thereafter (22). In the present study, serum osteocalcin levels were lower in older GS subjects than in younger GS subjects, and no such effect of age was demonstrated in controls. This finding must be interpreted with caution, however, because serum osteocalcin levels were similar in both older GS and control subjects. Moreover, bone resorption as assessed by CTX determinations was similar in the older and younger GS cohorts.

To date, many agents that lower serum unconjugated bilirubin levels have been identified. Most extensively studied are the barbiturates, which have been reported to normalize serum bilirubin levels in GS subjects (23). Somewhat less potent is rifampicin, which lowers unconjugated bilirubin levels by approximately $60 \%$ in subjects with GS (24). Most recently, the lipase inhibitor orlistat has been reported to significantly lower unconjugated bilirubin in Gunn rats (25); however, orlistat has yet to be studied in human GS subjects. Clearly, if subsequent studies demonstrate a causative effect between high serum unconjugated bilirubin levels and low BMDs, these and other agents may be of therapeutic value. However, their long-term costs, potential side effects and most importantly, their (yet to be demonstrated) value in lowering the risk of bone fractures must be considered before implementation for this purpose.

The results of the present pilot study lead to concerns regarding the long-term use of agents known to increase serum unconjugated bilirubin levels. For example, cyclosporine, a calcineurin inhibitor frequently used to prevent and treat rejection

\section{REFERENCES}

1. Okolicsanyi L, Nassuato G, Muraca M, et al. Epidemiology of unconjugated hyperbilirubinemia: Revisited. Semin Liver Dis 1988;8:179-82.

2. Blanckourt N, Fevery J. Chapter 11: Physiology and pathophysiology of bilirubin metablism. In: D Zakim, TD Boyer, eds. Hepatology. A textbook of Liver Diseases, 2 nd edn. Philadelphia: WB Saunders Company, 1990:282-5.

3. Kanis JA, Johnell O, Oden A, et al. Long-term risk of osteoporotic fracture in Malmo. Osteoporos Int 2000;11:669-74.

4. Melton IJ III, Chrischilles EA, Cooper C, Lane AW, Riggs BL. Perspective. How many women have osteoporosis? J Bone Miner Res 1992;7:1005-10.

5. Roullard S, Lane NE. Hepatic osteodystrophy. Hepatology 2001;33:301-7.

6. Floreani A, Chiaramonte M, Giannini S, et al. Longitudinal study on osteodystrophy in primary biliary cirrhosis (PBC) and a pilot study on calcitonin treatment. J Hepatol 1991;12:217-23.

7. Diamond TH, Stiel D, Lunzer M, McDowall D, Eckstein RP, Posen S. Hepatic osteodystrophy. Static and dynamic bone histomorphometry and serum bone Gla-protein in 80 patients with chronic liver disease. Gastroenterology 1989;96:213-21.

8. Bonkovsky HL, Hawkins M, Steinberg K, et al. Prevalence and prediction of osteopenia in chronic liver disease. Hepatology 1990;12:273-80.

9. Diamond T, Stiel D, Lunzer M, Wilkinson M, Roche J, Posen S. Osteoporosis and skeletal fractures in chronic liver disease. Gut 1990;31:82-7. in organ transplant recipients, interferes with unconjugated bilirubin uptake by hepatocytes (26). This property may help to explain, in part, the osteopenia that develops in transplant recipients (27). Moreover, many of the protease inhibitors presently used to treat patients with HIV infections inhibit bilirubin UDP-glucuronosyltransferase activity and thereby cause significant increases in serum unconjugated bilirubin levels (28-29). This may also help to partly explain the increased risk of osteoporosis in HIV-infected individuals undergoing long-term antiviral therapy $(30,31)$.

There are a several limitations that need be considered when interpreting the results of the present study. First, as is often the case with pilot studies, the number of subjects was small. Hence, the risk of type 1 and type 2 statistical errors were substantial. Second, the study design was cross-sectional. Ideally, a longitudinal study documenting changes in BMD and osteocalcin levels over time would have provided more compelling data. Finally, at this time, the unconjugated bilirubin, BMD and osteocalcin findings can only be interpreted as representing an association rather than an effect.

\section{CONCLUSION}

Together with previously published data indicating that unconjugated bilirubin inhibits osteoblastic proliferative activity in vitro, the results of the present pilot study provide sufficient justification for the design of future studies involving larger numbers of subjects monitored over a longer period of time to determine whether an association exists between chronic unconjugated hyperbilirubinemia and decreased BMD.

ACKNOWLEDGEMENTS: The authors thank the Health Sciences Centre Research Foundation for their support, and Ms T Chicheluk for her prompt and accurate typing of this manuscript. Ms R Greenberg is the recipient of a Canadian Liver Foundation Summer Student Award. There are no competing interests with respect to this study.
10. Masaki K, Shiomi S, Kuroki T, Tanaka T, Monna T, Ochi H. Longitudinal changes of bone mineral content with age in patients with cirrhosis of the liver. J Gastroenterol 1998;33:236-40.

11. Olsson R, Johansson C, Lindstedt G, Mellstrom D. Risk factors for bone loss in chronic active hepatitis and primary biliary cirrhosis. Scand J Gastroenterol 1994;29:753-6.

12. Stellon AJ, Davies A, Compston J, Williams R. Bone loss in autoimmune chronic active hepatitis on maintenance corticosteroid therapy. Gastroenterology 1985;89:1078-83.

13. Diamond T, Stiel D, Lunzer M, Wilkinson M, Roche J, Posen S. Osteoporosis and skeletal fractures in chronic liver disease. Gut 1990;31:82-7.

14. Janes CH, Dickson ER, Okazaki R, Bonde S, McDonagh AF, Riggs RL. Role of hyperbilirubinemia in the impairment of osteoblast proliferation associated with cholestatic jaundice. J Clin Invest 1995;95:2581-6.

15. Tenenhouse A, Joseph L, Kreiger N, et al; CaMos Research Group. Canadian Multicentre Osteoporosis Study. Estimation of the prevalence of low bone density in Canadian women and men using a populationspecific DXA reference standard: The Canadian Multicentre Osteoporosis Study (CaMos). Osteoporos Int 2000;11:897 -904.

16. Blake GM, Knapp KM, Spector TD, Fogelman I. Predicting the risk of fracture at any site in the skeleton: Are all bone mineral density measurement sites equally effective? Calcif Tissue Int 2006;78:9-17.

17. Clarke BL, Ebeling PR, Jones JD, et al. Predictors of bone mineral density in aging healthy men varies by skeletal site. Calcif Tissue Int 2002;70:137-45. 
18. Kanis JA. Diagnosis of osteoporosis and assessment of fracture risk. Lancet 2002;359:1929-36.

19. Marshall D, Johnell O, Wedel H. Meta-analysis of how well measures of bone mineral density predict occurrence of osteoporotic fractures. BMJ 1996;312:1254-9.

20. Garnero P, Delmas PD. Bone Markers. Baillieres Clin Rheumatol 1997;11:517-37.

21. Garnero P, Sornay-Rendu E, Chapuy MC, Delmas PD. Increased bone turnover in late postmenopausal women is a major determinant of osteoporosis. J Bone Miner Res 1996;11:337-49.

22. Midtby M, Magnus JH, Joakimsoen RM. The Tromso Study: A population-based study on the variation in bone formation markers with age, gender, anthropometry and season in both men and women. Osteoporos Int 2001;12:835-43.

23. Lovisetto P, Giorcelli W, Actis GC, Biarese V. Gilbert's jaundice. Current clinico-nosographic, physiopathological and therapeutic aspects. III. Therapeutic action of enzyme inductors with reference to unconjugated bilirubin icterus. Minerva Med 1977;68:73-81.

24. Ellis E, Wagner M, Lammert F, et al. Successful treatment of severe unconjugated hyperbilirubinemia via induction of UGT1A1 by rifampicin. J Hepatol 2006;44:243-5.

25. Hafkamp AM, Havinga R, Sinaasappel M, Verkade HJ. Effective oral treatment of unconjugated hyperbilirubinemia in Gunn rats. Hepatology 2005;41:526-34.

26. Campbell SD, de Morais SM, Xu JJ. Inhibition of human organic anion transporting polypeptide OATP 1B1 as a mechanism of druginduced hyperbilirubinemia. Chem Biol Interact 2004;150:179-87.

27. Goffin E, Devogelaer JP. Bone disorders after organ transplantation. Transplant Proc 2005;37:2832-3.

28. Zucker SD, Qin X, Rouster SD, et al. Mechanism of indinavirinduced hyperbilirubinemia. Proc Natl Acad Sci USA 2001;98:12671-6.

29. Orrick JJ, Steinhart CR. Atazanavir. Ann Pharmacother 2004;38:1664-74.

30. Prior J, Burdge D, Maan E, et al. Fragility fractures and bone mineral density in HIV positive women: A case-control populationbased study. Osteoporos Int 2007;18:1345-53.

30. Bongiovanni M, Fausto A, Cicconi P, et al. Osteoporosis in HIVinfected subjects: A combined effect of highly active antiretroviral therapy and HIV itself? J Acquir Immune Defic Syndr 2005;40:503-4.

31. Annapoorna N, Rao GV, Reddy NS, Rambabu P, Rao KR. An increased risk of osteoporosis during acquired immunodeficiency syndrome. Int J Med Sci 2004;1:152-64. 


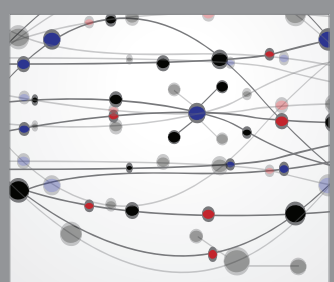

The Scientific World Journal
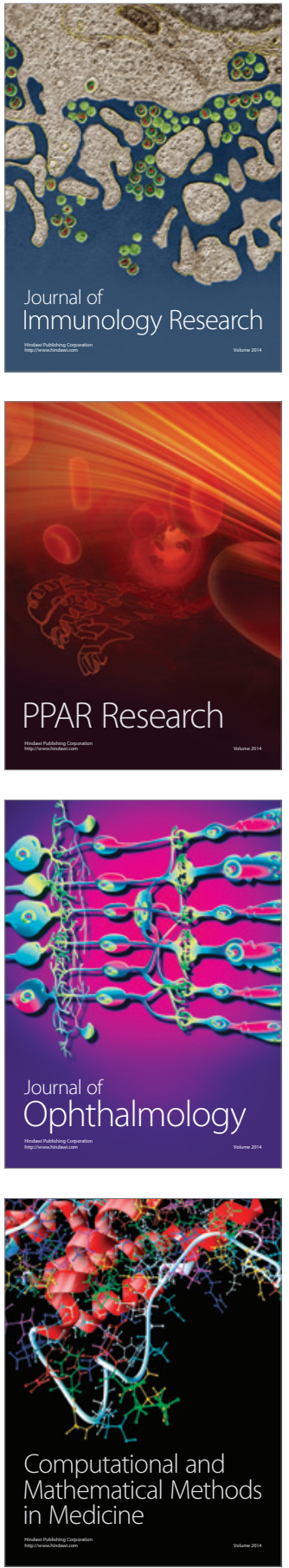

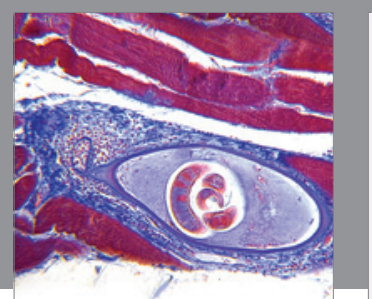

Gastroenterology Research and Practice

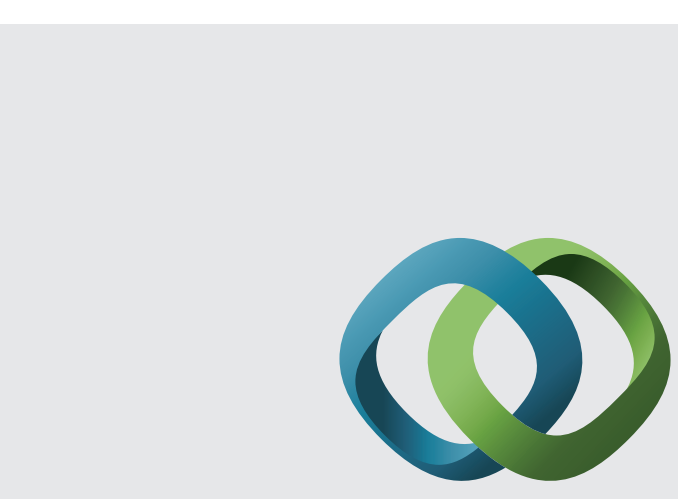

\section{Hindawi}

Submit your manuscripts at

http://www.hindawi.com
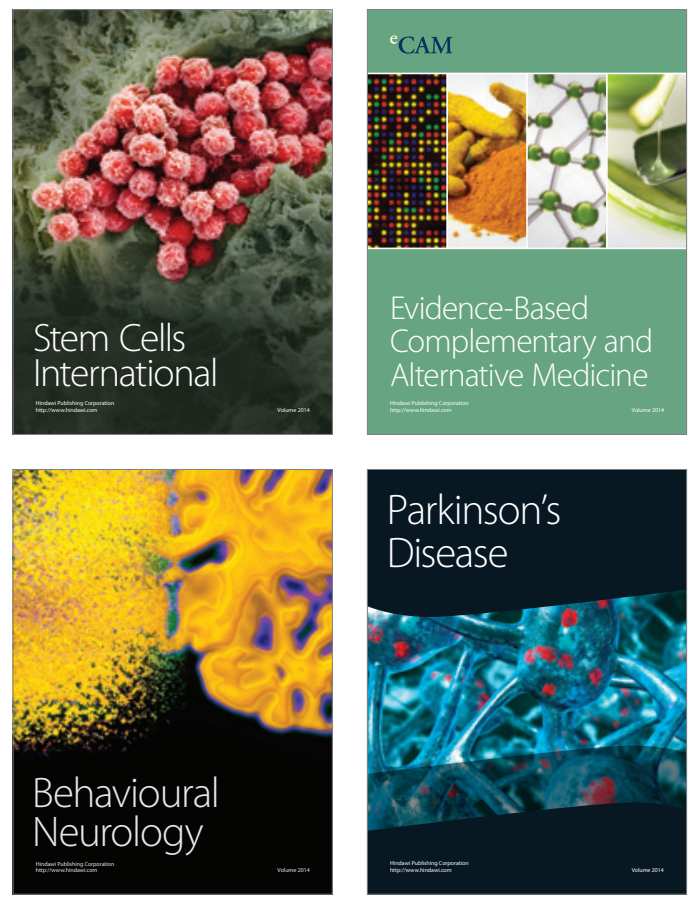
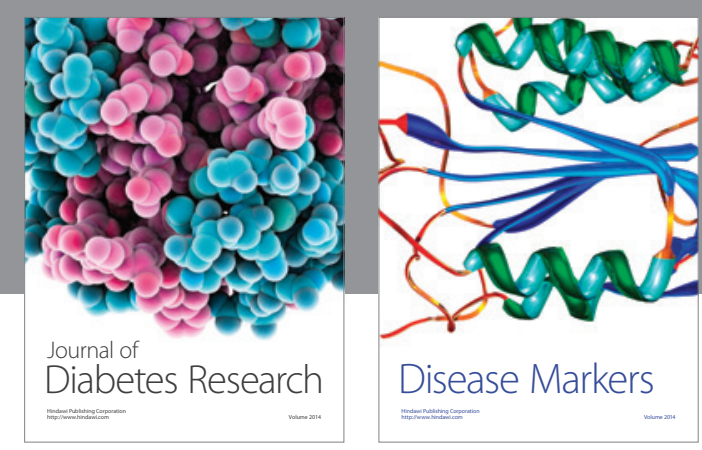

Disease Markers
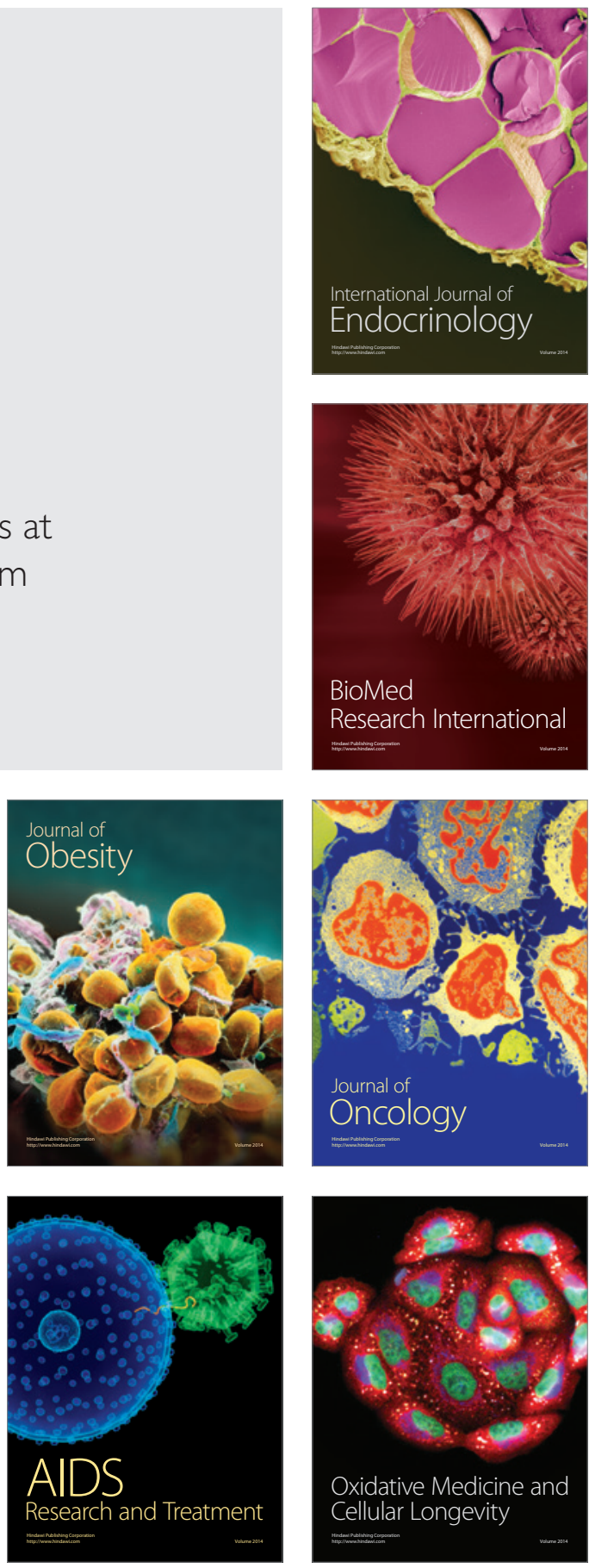